\title{
Hugh of St Victor's Influence on the Summa Halensis
}

\begin{abstract}
The influence of the $12^{\text {th }}$ century Victorines, especially that of Hugh and Richard of St Victor, on the Summa Halensis, is pervasive, both deep and wide. The Halensist quotes both authors explicitly and frequently. A catalogue of Hugh citations would reveal one kind of perspective on Hugh's influence on various topics, especially on the sacraments in the unedited Book IV of the Summa. Arguably more important, though, is Hugh's influence on the entire orientation and method of the early Franciscan Summa. Three aspects of this form of influence are noteworthy. First, the Halensist adopts and adapts Hugh's signature distinction between the two fundamental 'works of God', namely, creating and restoring, as a framework for organizing the content of the entire Summa. Second, the Halensist identifies the overarching subject matter of theology as the Hugonian 'works of restoration' in salvation history, centered on the Incarnation. Third, the Halensist is inspired by Hugh to conceive of theology as a practical discipline, aimed ultimately at perfecting its practioner affectively by orienting her in love toward divine goodness. In this, theology is a distinct form of Christian wisdom.
\end{abstract}

Assessing the influence of Hugh of St Victor (d. 1241) on the Summa Halensis (SH), it seems fitting to begin with Bonaventure's oft-cited praise of the Victorine in On the Reduction of the Arts to Theology. ${ }^{1}$ There, surveying the luminaries of the recent and remote Christian tradition, the Seraphic Doctor paid special tribute to Hugh. The Franciscan observed that Augustine and Anselm excelled in speculative theology, Gregory the Great and Bernard of Clairvaux in practical morality, and Dionysius and Richard of St Victor in mystical contemplation. But Hugh 'excelled in all three'.2 Bonaventure's paean to Hugh is oft-noted, but still noteworthy: It is very high praise, especially in light of the fact that the medievals themselves highly val-

\footnotetext{
1 Bonaventure, 'On Retracing the Arts to Theology 5,' in The Works of Bonaventure, vol. 3, trans. José de Vinck (Paterson, NJ: St Anthony's Guild Press, 1966), 20.

2 Bonaventure, De reductione artium ad theologiam, in Doctoris seraphici S. Bonaventurae opera omnia, vol. 5 (Quaracchi: Collegii S Bonaventura, 1891), 321: 'Unde tota sacra Scriptura haec tria docet, scilicet Christi aeternam generationem et incarnationem, vivendi ordinem et Dei et animae unionem. Primum respicit fidem, secundum mores, tertium finem utriusque. Circa primum insudare debet studium doctorum, circa secundum studium praedicatorum, circa tertium studium contemplativorum. Primum maxime docet Augustinus, secundum maxime docet Gregorium, tertium vero docet Dionysius; Anselmus sequitur Augustinum, Bernardus sequitur Gregorium, Richardus sequitur Dionysium, quia Anselmus in ratiocinatione, Bernardus in praedicatione, Richardus in contemplatione. Hugo vero omnia haec.'
}

2 OpenAccess. (C) 2020 Lydia Schumacher, published by De Gruyter. (cc))BY-NC-ND This work is licensed under the Creative Commons Attribution-NonCommercial-NoDerivatives 4.0 License. 
ued comprehensive, synthetic integration. To unite everything into a coherent and indeed beautiful whole, like a gothic cathedral, an institutional universitas, or a theological Summa-'where there is a place for everything and everything has its place'was for high medieval culture the consummate human achievement. To position Hugh thus, not merely as the exemplar in one part or aspect, but of all-le modèle $d u$ théologien accompli ${ }^{3}$-is to put him at the pinnacle of all that a high medieval theologian might esteem.

Another point is germane. Bonaventure's esteem for Hugh is often considered in isolation-a tribute from one theological virtuoso to another. The Franciscan casts his eyes back over an intervening century to the venerable Victorine, perhaps, given the former's purported ambivalence about the trajectory of scholastic culture in his own day, with a whiff of nostalgia for a bygone era when things were right in the theological world. Quite probably, though, contemporary Franciscan readers would not have been startled by this homage-as modern readers tend to be-nor would they have heard it as a wistful retrospect to a now quaint theological enterprise. Rather, they may well have found it an obvious commonplace. As J.G. Bougerol pointed out long ago, ${ }^{4}$ a distinctive $13^{\text {th }}$-century Franciscan interest in the Victorines (in contrast to the Dominicans), in Hugh certainly but also in Richard, ${ }^{5}$ was already deeply imbedded in Franciscan intellectual culture by Bonaventure's time. In fact, it began with Alexander of Hales, ${ }^{6}$ founder of the Franciscan school and Bonaventure's own revered master. This may well be a function of Alexander's close relationship with the Abbey of St Victor in Paris, and to its regent master in the first two decades of the $13^{\text {th }}$ century, Thomas Gallus. ${ }^{7}$ Beginning with Alexander's Gloss on the Lom-

3 Sylvain Piron, 'Franciscains et victorins: Tableau d'une réception,' in L'école de Saint-Victor de Paris: Influence et le rayonnement du Moyen Âge à l'Époque modern, ed. Dominique Poirel, Bibliotheca Victorina, 22 (Turnhout: Brepols, 2010), 522.

4 Jacques Guy Bougerol, Introduction à Saint Bonaventure (Paris: Vrin, 1988), 94.

5 Piron, 'Franciscains et victorins,' 526, notes that as an Englishman, 'Alexander undoubtedly played a role in the importation into Paris of the writings of the Archbishop of Canterbury who never seems to have been quoted with such frequency by the masters of previous generations. But it is probably in Paris that he encountered the works of his compatriot Richard.'

6 See Victorin Doucet, 'Prolegomena,' in Alexander of Hales, Magistri Alexandri de Hales Glossa in quatuor libros Sententiarum Petri Lombardi, 4 vols, Bibliotheca Franciscana Scholastica Medii Aevi,

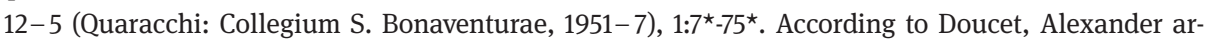
rived in Paris in the first decade and was regent master in the faculty of arts (as Roger Bacon mentions) prior to the prohibition against lectures on the physical books of Aristotle in 1210. He then seems to have shifted over to the faculty of theology in 1212 to 1213 , where he became successively student, bachelor, and regent master in 1220 or 1221. In 1236, he became a Franciscan, which was the occasion of a transfer of his university chair into the Franciscan Order. The first Franciscan theological school coalesced around him.

7 Bougerol, Introduction à Saint Bonaventure, 94, hypothesized that in fact Alexander was first the student, and then the successor of the last great Victorine master, Thomas Gallus or Thomas of Saint-Victor, who was teaching at the Abbey until 1219, when he departed for Vercelli (cf. Gabriel Théry, 'Thomas Gallus: aperçu biographique,' Archives d'histoire doctrinale et littéraire du Moyen 
bard's Sentences, and continuing in his disputed questions, Hugh is a consistent presence in Alexander's authentic writings. Not only that: the frequency of Hugh citations only increases (as does the percentage relative to other authors) in the $S H .{ }^{8}$ As the edition editors noted, the $S H$ 'is greatly indebted to the masters of the school of St Victor'.9

Bonaventure's tribute to Hugh, then, is symptomatic of a well-established 'Victorine-Franciscan' worldview, sensibility, and tradition running from the early $12^{\text {th }}$ century to the mid $13^{\text {th }},{ }^{10}$ terminating in St Bonaventure. ${ }^{11}$ Modern historians ought

Âge 12 (1939): 163). Thus, Alexander's accession to the rank of master and the beginning of his regen-
cy follows hard, intriguingly, on Gallus' departure. On this theory, accordingly, the chair of the Abbey
of Saint-Victor would have thus passed to a secular master (Alexander), on the assumption that no
Victorine canon was qualified to assume it (Piron, 'Franciscains et victorins,' 527). Bougerol also
noted that on January 26, 1237, Gregory IX issued a papal bull granting a new chair of theology to
Saint-Victor, just a few months after Alexander joined the Franciscans in 1236. In the bull, Gregory
notes that teaching at Saint-Victor had been 'interrupted for some time' (aliquandiu intermissa), per-
haps because of Alexander's departure. Bougerol's theory is based largely on circumstantial evi-
dence, namely, this double coincidence of dates, along with the traces of intellectual continuity be-
tween Alexander and the Victorines. Other scholars have disputed it (cf. Jacques Verger, 'Saint-Victor
et l'université,' in L'école de Saint-Victor de Paris (see above, n. 3), 139-152). Though an attractive
theory, it seems safest to say that the evidence remains inconclusive. 8 See the statistical tabulation in Piron, 'Franciscains et victorins,' 525. As he notes at 526, that Alexander refers to Hugh and Richard as magister hints at a more intimate relationship than mere familiarity with their texts.

9 'Prolegomena ad primum librum Summae Theologicae,' in Alexander of Hales, Doctoris irrefragabilis Alexandri de Hales Ordinis minorum Summa theologica, vol. 1 (Quaracchi: Collegium S. Bonaventurae, 1924), Xxxiv: 'A magistris quoque scholae S. Victoris valde dependet Doctor noster'.

10 The Victorines influenced other important figures in the early Franciscan movement, including St Anthony of Padua, who seems to have known and revered Thomas Gallus (cf. Gabriel Théry, 'Saint Antoine de Padoue et Thomas Gallus: I. Formation du thème vercellien,' La vie spirituelle 37 (1933): 94-115; Gabriel Théry, 'Saint Antoine de Padoue et Thomas Gallus: II. Critique du thème vercellien,' La vie spirituelle 37 (1933): 163-70; Gabriel Théry, 'Saint Antoine de Padoue et Thomas Gallus: III. L'éloge de S. Antoine de Padoue par Thomas Gallus,' La vie spirituelle 38 (1934): 22-51; see also Jean Châtillon, 'Saint Antoine de Padoue et les victorins,' Il Santo 22 (1982): 171-202, republished in Jean Châtillon, Le mouvement canonial au Moyen Âge: réforme de l'Église, spiritualité et culture, ed. Patrice Sicard, Bibliotheca Victorina, 3 (Paris/Turnhout: Brepols, 1992), 255-92). As Piron notes, Anthony had been trained in Lisbon and especially in Coimbra, with regular canons, who read Victorine writers, some of whom might have even studied in Paris with Gallus. Anthony also seems to have spent time studying with the Parisian-trained Gallus in Vercelli, perhaps coinciding with an attempt to found a university there in 1228 , which involved attracting the masters and students of Padua (Piron, 'Franciscains et victorins,' 528).

11 Gilson saw this nearly a century ago: 'Such works testify amply, and they will testify more and more, as they are studied, of the intense vitality manifested by Christian thought towards the end of the twelfth century and the beginning of the thirteenth century. Far from appearing to us as a messy site occupied by teams of anarchic workers and powerless to build, it appears to us as resolutely engaged since the time of Victorines in the way that leads to St Bonaventure. Of essentially theological inspiration, it uses, without false shame, the terminology or even the doctrine of Aristotle, but under the express condition that none of its constituent principles will ever come to replace those 
to adopt the notion that a continuous, coherent, and compelling theological tradition -distinguishable from other contemporary currents ${ }^{12}$-flows between Hugh and Bonaventure, with Alexander and the $\mathrm{SH}$ as the conduit between them. One might even see the nascent Franciscan theological tradition as the early $13^{\text {th }}$-century form and expression, even sublimation, of the Victorine school.

Bonaventure's praise of Hugh harbors one last feature relevant to the Victorine's influence on the early Franciscan intellectual tradition. As in the praise itself, the significance of Hugh's presence in the $S H$ is less related to a particular doctrine or aspect of the theological enterprise (e.g. sacraments or contemplation), though Hugh is cited as an authority on many such topics ${ }^{13}$-too numerous to catalogue here, especially in Book 4, on the topics of the sacraments. Rather, it is more ambient, atmospheric, and global, more an underlying theological sensibility and orientation. Three such aspects, all from the 'General Introduction' of the $S H$, are treated below.

\section{Hugh's 'Two Works' and the Structure of the Summa Halensis}

In order to appreciate the first area of Hugh's influence on Alexander, a brief glance at the opening lines of Hugh's great masterwork, the De sacramentis, is necessary. ${ }^{14}$ With a certain methodological self-consciousness at the dawn of medieval scholasticism, Hugh begins by specifying the nature of his undertaking in this way:

of Augustine in the edifice built by tradition' (Étienne Gilson, La philosophie de Saint Bonaventure (Paris: Vrin, 1924), 468).

12 This is not to deny the presence of other important theological currents flowing into the Summa Halensis, including those from Augustine of Hippo, John of Damascus, Anselm of Canterbury, and Peter Lombard. Cf. 'Prolegomena ad primum librum Summae Theologicae,' xxviII: '1. Alexander Halensis in conscribenda Summa Theologica doctrinas philosophicas et theologicas a S. Augustino, S. Anselmo et schola Sancti Victoris praecipue excogitates et iam in academiis Medii Aevi usu receptas, fidelissime amplectitur. Etenim decursu saeculorum, sapientia christiana motu quodam progressivo in synthesim organicam sese constituerat, ut videre est praesertim in libro De Trinitate S. Augustini, in De fide orthodoxa Ioannis Damasceni, in Summis De Sacramentis et De Trinitate Hugonis et Richardi a S. Victore, in quatuor Libris Sententiarum Petri Lombardi et in aureis opusculis, Monologion et Proslogion, S. Anselmi.'

13 The editors mention several, but there are many others. Cf. 'Prolegomena ad primum librum Summae Theologicae,' xxxIv: 'In primis distinctionem Hugonis a S. Victore inter opera conditionis et opera recreationis agnoscit (n. 3, ad 1, 2, 4, p. 6-7). Ad mentem eius tractat de statu primi hominis (n. 146, p. 225) et de cognitione quam Adam de Deo habebat in paradiso (n. 18, p. 29). Illum prae ceteris laudat in quaestione de differentiis voluntatis divinae in generali (n. 272, p. 369b).'

14 Hugh of St Victor, De sacramentis (hereafter, Sacr.) (PL 176:173 A-618B); Hugh of St Victor, On the Sacraments of the Christian Faith (De sacramentis), trans. Roy J. Deferrari, Medieval Academy of America, 58 (Cambridge, Mass.: Mediaeval Academy of America, 1951). 
The subject matter of all the divine Scriptures is the work of restoration (opera restaurationis) of humanity. For there are two works in which is contained all that has been done. The first is the work of creation (opus conditionis). The second is the work of restoration (opus restaurationis). The work of creation is that whereby those things which were not came into being. The work of restoration is that whereby those things which had been impaired were made better. Therefore the work of creation is the creation of the world with all its elements. The work of restoration is the Incarnation of the Word with all its sacraments, both those which have gone before from the beginning of time, and those which come after, even to the end of the world. ${ }^{15}$

He then concludes this introductory discussion with the following:

Therefore, the works of creation (opera creationis), as of little importance, were accomplished in six days, but the works of restoration (opera restaurationis) can only be completed in six ages. Yet six are placed over against six that the Restorer may be proven to be the same as the Creator. $^{16}$

From much that could be said of these texts, three features merit mention: First, the distinction between the two works, namely, of creation and of restoration, is a distinctive Hugonian marker, a fundamental, far-reaching, and signature distinction in his theology. The second feature is the emphasis on divine activity in history ('salvation-history' in modern terms), in creating, but especially in restoring fallen creation; i.e. the 'works of restoration'. Christological centrality is the third: Christ is the center of God's activity in salvation history, and all those acts are 'sacraments' (another piece of distinctive Hugonian vocabulary) mediating divine self-revelation. In short, for Hugh, the subject matter of all of Scripture, what the whole of Scripture is ultimately about, is salvific divine activity in history, centered around the Incarnation.

In light of Hugh's text, consider the continuity of themes and the persistent $\mathrm{Hu}$ gonian orientation found in the opening paragraphs of the 'General Prologue' of the SH: 'The whole discipline of Christian faith pertains to two things: to the faith and

15 Hugh of St Victor, Sacr., I.Prol.2 (Deferrari, 3; PL 176:183 A-B): 'Materia divinarum Scripturarum omnium sunt opera restaurationis humanae. Duo enim sunt opera in quibus universa continentur quae facta sunt. Primum est opus conditionis. Secundum est opus restaurationis. Opus conditionis est quo factum est ut essent quae non erant. Opus restaurationis est quo factum est ut melius essent quae perierant. [183B] Ergo opus conditionis est creatio mundi cum omnibus elementis suis. Opus restaurationis est incarnatio Verbi cum omnibus sacramentis suis; sive iis quae praecesserunt ab initio saeculi, sive iis quae subsequuntur usque ad finem mundi.'

16 Hugh of St Victor, Sacr., I.Prol.2 (Deferrari, 4; PL 176:184 A): 'Propterea illa [opera conditionis] quasi modicum aliquid sex diebus perfecta sunt; haec [opera restaurationis] vero non nisi aetatibus sex compleri possunt. Tamen sex contra sex e diverso ponuntur, ut idem reparator qui creator demonstretur.' 
understanding of the Creator and the faith and understanding of the Savior. ${ }^{17}$ The Halensist then elaborates on each:

The faith [and understanding] of the Creator principally contains two things, namely, the cognition of the substance of the Creator and the cognition of the works of the Creator. The cognition of the substance of the Creator consists in the cognition of the divine Unity and of its most blessed Trinity, while the cognition of the works of the Creator consists in the cognition of the creation or formation of things. ${ }^{18}$

And:

Likewise, the faith and understanding of the Savior revolves around two things, namely, around the person of the Savior and around the work of salvation. And the person of the Savior is the person of the Son of God, namely, Christ in two natures, of divinity and of humanity. For Christ is one, God and man. ${ }^{19}$

Between the Victorine and the Halensian is a shared interest in divine activity in history-the divine opera. ${ }^{20}$ Distinctive to the latter is the interest in the divine Actor, as well (more on this below). It may also be the case that the Halensist grants the two

17 Alexander of Hales, Doctoris irrefragabilis Alexandri de Hales Ordinis minorum Summa theologica (SH), 4 vols (Quaracchi: Collegium S. Bonaventurae, 1924-48), Vol I, 'Prologus Generalis': 'Tota christianae fidei disciplina pertinet ad duo: ad fidem et intelligentiam Conditoris et fidem atque intelligentiam Salvatoris. Unde Isaias Propheta, in persona Domini loquens, dicit, 43:10 - 11: "Credatis et intelligatis quia ego ipse sum: ante me non est formatas deus et post me non erit. Ego sum, ego sum Dominus, et non est absque me Salvator.",

18 SH I, 'Prologus Generalis': 'Fides enim [Conditoris] principaliter continet duo, scilicet cognitionem substantiae Conditoris et cognitionem operis Conditoris. Cognitio substantiae Conditoris consistit in cognitione divinae Unitatis et eiusdem beatissimae Trinitatis; cognition vero operis Conditoris consistit in cognitione creationis rerum seu formationis. Unde Propheta signanter dixit quantum ad cognitionem substantiae: "Intelligatis quia ego sum”; Ex. 3:14: "Ego sum qui sum”; quantum ad cognitionem operis subdidit: "Ante me non est formatas deus”, a quo sit principium universae creationis.'

19 SH I, 'Prologus Generalis': 'Item, fides et intelligentia Salvatoris versatur circa duo, scilicet circa personam Salvatoris et circa opus salvationis. Persona autem Salvatoris est persona Filii Dei, scilicet Christus in duabus naturis, divinitatis scilicet et humanitatis: Deus enim et homo unus est Christus. Unde ad significandum personam Salvatoris in natura divinitatis dicit: "Ego sum", cui scilicet competit nomen quod est Ex. 3:14: “Qui est misit me ad vos”. Ad significandum eamdem personam in natura humanitatis addit: "Ego sum Dominus"; unde in Rev. 19:16: "Habebat in vestimento suo et in femore suo scriptum: Rex regum et Dominus dominantium.” Opus salvationis consistit in sacramentis salutis per praesentem gratiam et praemiis salutis per futuram gloriam. Ad quod designandum addit: "Et non est absque me Salvator", a quo scilicet sit principium et causa nostrae salvationis; Hos. 13:4: "Deum absque me nescies, et Salvator non est praeter me."

20 Elisabeth Gössmann, Metaphysik und Heilsgeschichte: Eine theologische Untersuchung der Summa Halensis (Munich: Max Huber Verlag, 1964) briefly discusses Hugh of St Victor's influence on the notion of the subject matter of theology in the $\mathrm{SH}$, but not at the level of detail pursued below. 
works a greater symmetry of importance than Hugh did, thus reflecting a deeper interest in a doctrine of creation.

However that may be, this Hugonian interest in the works of creation and restoration, coupled with the Halensist's additional attention to the Agent of both, becomes the organizing conceit of the entire $\mathrm{SH}$, which the Halensist explains as he concludes the 'Prologue':

The Catholic inquiry, therefore, concerning those things which pertain to the faith is four-part: [Book I] pertains to the cognition of the substance of the divine Trinity and Unity; [Book II] pertains to] the works of divine creation; [Book III] pertains to the person of the Savior in his divinity and humanity; [Book IV] pertains to the sacraments of salvation and the work of future glorification. $^{21}$

While it is true that Peter Lombard's Four Books of Sentences is also roughly divided in a similar way (on which a Hugonian influence is certainly possible if not probable), the Halensist's own explanation of the structure in terms of two fundamental salvation-historical theaters of activity, with their common divine Agent, is strikingly redolent of Hugh. Slightly later, the Halensist uses even more explicit Hugonian language in returning to the equally Hugonian accent on the work of human restoration:

From the aforesaid it is clear that the doctrine of theology is about God accomplishing the work of human restoration through Christ. Thus the parts of the first inquires of theology are concerned with the excellence of the divine sublimity, but the following parts concern Christ and pertain to the work of repair. ${ }^{22}$

In short, the concern with the works of both creation and salvation reflects the $\mathrm{Hu}$ gonian approach; the interest in linking works back to their Agent adumbrates an emerging concern of the SH's general approach to theology.

\section{The 'Works of Restoration' and the Subject Matter of Theology}

After the 'General Prologue' just discussed, there follows an 'Introductory Treatise', which takes up a variety of issues related to the basic question: 'What is the nature

21 SH I, 'Prologus Generalis': 'Inquisitio igitur catholica de iis quae pertinent ad fidem quadripartita est: prima pars pertinet ad cognitionem substantiae divinae Trinitatis et Unitatis; secunda ad opera divinae conditionis; tertia ad personam Salvatoris in natura divinitatis et natura humanitatis; quarta vero pertinet ad sacramenta salutis et opera futurae glorificationis.'

22 SH I, TrInt, Q1, C 4, Ar4 (n. 7), Ad obiecta 1-2, p. 13: 'Ex praedictis manifestum est quod doctrina Theologiae est de substantia Dei efficiente per Christum opus reparationis humanae. Ideo partes primae inquisitionis theologicae sunt circa excellentiam divinae sublimitatis, consequentes vero erunt de Christo et pertinentibus ad opus reparationis.' 
of theology?' The analysis divides into four sub-questions: 1. Is theology a science? 2. How is it like or unlike other 'sciences', namely, philosophy and the liberal arts? 3. What is its proper object, its subject matter? and 4. What is theology's mode of proceeding?

The $S H$ is anxious to affirm the scientific status of theology as much as possible in comparison with Aristotelian canons for what counts as such. In particular, it pursues an extended comparison with Aristotelian metaphysics. At present, it is theology's subject matter, what theology is about, that is of interest.

To begin, the $S H$ considers three $12^{\text {th }}$-century answers to this question. Is its subject matter 'signs and things' as Peter Lombard, following Augustine, has it in his Sentences? Is it 'the whole Christ, both Head and Body, Christ and the Church, the groom and the bride', as apparently suggested by the Glossa Ordinaria and taken up by Robert of Melun, Gilbert of Poitiers, Robert Grosseteste and Robert Kilwardby? ${ }^{23}$ Or is it 'the works of restoration' as Hugh of St Victor argued?

Initially, in light of a comparison with metaphysics, the $S H$ sets all three proposals aside, including Hugh's:

the subject matter which [first philosophy] is about is everything-whence it is said to be about (de) all things, since it treats being (ens), according to its every difference, according to the different divisions of being, namely, being in potency, being in act, being as one and many, being as subject and accident, and so on-but principally its subject matter is being as one in act, which is the first substance, on which all beings depend..$^{24}$

That is, even though in one sense the science of metaphysics considers everything that is, its primary or principal subject matter is being (ens/esse) itself, the first substance, the cause of causes. To the extent that it also treats all other beings it treats these, not with respect to their distinctive natures (as the other sciences do), but simply in so far as they exist.

The $S H$ follows suit here. It is anxious to assert that the principal object or subject matter of theology is God. So, singling out Hugh's proposal in particular, its response is to object:

23 See James A. Weisheipl, 'The Meaning of Sacra Doctrina in Summa Theologiae I, q. 1,' The Thomist 38 (1934): 75.

24 SH I, TrInt, Q1, C3 (n. 3), Ad obiecta 3, p. 7: 'Quemadmodum est dicere de Philosophia Prima quod materia circa quam est sunt omnia-unde et dicitur esse de omnibus, quia est circa ens secundum omnem sui differentiam, secundum. differentes divisiones entis, scilicet ens potentia, ens actu, eris unum et multa, ens substantia et accidens, et huiusmodi-materia vero de qua intentio, est ens actu unum, quod est substantia prima, a qua omnia dependent.' 
To the contrary ( ... ) theology is a science about (de) God; thus, it is a science about the cause of the works of both creation and restoration. Thus, the subject of sacred Scripture is not the works of restoration, but rather their very cause, which is God. ${ }^{25}$

In sum, the principal subject matter of theology must thus be God; Hugh's proposal seems to be set aside.

But here the similarity between theology and Aristotelian metaphysics breaks down, as the $S H$ well knows. For Aristotle had also claimed that: 'A single science is one whose domain is a single genus, whose parts and essential properties it considers per se. ${ }^{26}$ Any genuine science, accordingly, must not only have a single subject matter, but it must also have essential knowledge of that object, and then be able to analyze it according to its essential properties and parts. The $\mathrm{SH}$ recognizes, though, that the theologian does not have the benefit of an essential definition of God, 'with respect to the mystery of the Trinity'. Citing this very text from Aristotle, it thus argues that theological science must take a different tack: with respect to 'the very divinity and trinity of persons', in theology 'there is another way of knowing' ${ }^{27}$ In fact, it is the inverse of the Aristotelian way. Rather than beginning with a known essence and analyzing its essential characteristics, the theologian must begin with revealed characteristics and reason back to the divine essence. Citing Rom. 1:20 to its purpose, the SH puts it thus: 'theology must proceed from knowledge of divine action to knowledge of divine power, and then to knowledge of the divine substance itself. ${ }^{28}$

With these preliminary affirmations regarding the nature of theology squarely in view, the $S H$ now proceeds to its resolution:

The subject "about which" (de qua) can be taken in three ways, according to the words of Dionysius in The Angelic Hierarchy: "All understanding of the divine is divided by the heavenly intelligence into three: essence, power, and operation." According to this, if we take the subject of sacred Scripture in the sense of 1. "operation", we can say that it is the works of restoration of humankind. If, however, we take the subject of sacred Scripture in the sense of 2. "power", we shall say that it is Christ, who is "the power and wisdom of God" (1 Cor. 1:24). If, finally, we take the subject of sacred Scripture in the sense of 3. "essence", we shall say that it is God, or the divine substance. Whence, according to this, theology is a science about the divine substance

25 SH I, TrInt, Q1, C3 (n. 3), Contra 2, p. 5: 'Item, Theologia est scientia de Deo; ergo est scientia de causa operum conditionis et reparationis; non igitur materia divinarum Scripturarum erunt opera reparationis, sed magis ipsa causa, quae Deus est.'

26 SH I, TrInt, Q1, C1 (n. 1), Ad obiecta 4, p. 4, citing Posterior Analytics I: 'Item, adhuc obiciet aliquis sic: "Omnis scientia est alicuius generis subiecti, cuius partes et passiones per se considerat", sicut dicit Philosophus.'

27 SH I, TrInt, Q1, C1 (n. 1), Ad obiecta 4, p. 4: 'Velut est ipsa divinitas et trinitas personarum, est modus cognoscendi alius.'

28 SH I, TrInt, Q1, C1 (n. 1), Ad obiecta 4, p. 4: 'Ut per operationem cognoscamus virtutem, per virtutem ipsam divinitatis substantiam.' 
which must be cognized through Christ in the work of restoration (de substantia divina cognoscenda per Christum in opere reparationis). ${ }^{29}$

Strikingly, the $\mathrm{SH}$ seems here to fuse Hugh and Aristotle, with a little help from Dionysius. As with Aristotelian metaphysics, the primary and principal subject matter of theology is God in se. Yet, in light of theology's necessarily distinctive 'way of knowing', which must begin with the divine works, the $S H$ has made the Hugonian 'works of restoration', the Trinity's salvation-historical activity ad extra, integral and indeed crucial to its notion of theology. (In fact, since Hugh's 'works of restoration' are profoundly Christocentric - 'the work of restoration is the Incarnation of the Word with all its sacraments ${ }^{30}$-the reference to the power of Christ in Alexander's formula is arguably Hugonian too.)

Replying to the objections, accordingly, the $\mathrm{SH}$ explicitly 'rehabilitates' the Hugonian proposal about the proper subject matter of theology. Conceding that theology is indeed about the cause of the work of restoration and creation, the $\mathrm{SH}$ nonetheless insists that: 'it does not follow from this that the subject matter of theology is not the works of restoration,' since 'the highest cause, which is God, is revealed through the work of restoration, through the power of Christ. ${ }^{, 31}$

In short, the $S H$ has adopted fully Hugh's definition of theology, but has situated it within a theological framework deeply indebted to Aristotelian metaphysics, wherein theology must ultimately-indeed speculatively- be about God in $s e .^{32}$

29 SH I, TrInt, Q1, C3 (n. 3), Respondeo, p. 6: 'Materia dupliciter accipitur in scientiis 'de qua' et 'circa quam'. 'Materia de qua' potest assignari tripliciter, secundum illud B. Dionysii, in Hierarchia angelica: "In tria dividuntur supermundana ratione omnes divini intellectus: in essentiam, virtutem et operationem." Secundum hoc ergo, si assignemus materiam divinarum Scripturarum secundum rationem operationis, dicemus quod materia divinarum Scripturarum sunt opera reparationis humani generis. Si vero assignemus materiam divinarum Scripturarum secundum rationem virtutis, dicemus quod materia divinarum Scripturarum est Christus, qui est Dei virtus et Dei sapientia, I Cor. 1, 24. Si vero assignemus materiam divinarum Scripturarum secundum rationem essentiae, dicemus quod materia divinarum Scripturarum est Deus sive divina substantia. Unde secundum hoc Theologia est scientia de substantia divina cognoscenda per Christum in opere reparationis.'

30 Hugh of St Victor, Sacr., I.Prol.2 (Deferrari, 3; PL 176:183 A-B): 'Opus restaurationis est incarnatio Verbi cum omnibus sacramentis suis.'

31 SH I, TrInt, Q1, C3 (n. 3), Ad obiecta 2, p. 6: 'Ad secundum vero quod obicitur contra eumdem, quod "Theologia est de causa operum recreationis et conditionis" concedendum est. Non tamen ex hoc sequitur quod materia divinae Scripturae non sint opera reparationis, quia summa causa, quae Deus est, declaratur per opus reparationis, per virtutem Christum, sicut dictum est, ut in operatione cognoscamus virtutem et in virtute divinitatem ( ... ).'

32 Gössmann, Metaphysik und Heilsgeschichte, 25-6, observes: 'Theology, according to the Summa Halensis, deals thus with the knowledge of the divine being (Wesenserkenntnis) of the Trinitarian God, known through Christ in his saving work (Erlösungswerk), though one must take the opus restaurationis more in the broad sense that Hugh of St Victor gave it ( ... ) Thus the salvation-historical dimension is taken directly into the definition of theology (Gegenstandsbestimmung). It provides divine essence, not in the modest way of Aristotelian prima philosophia, but rather in its Trinitarian fullness. There is an emphasis on the fundamental difference between the remaining-hiddenness (Verborgenbleiben) of 
That is, theology is like first philosophy or metaphysics, which is also about the 'cause of causes', but unlike metaphysics, theology is 'about God' (de Deo) 'insofar as God is the mystery of the Trinity' and 'according to the sacrament of restoration' (secundum mysterium Trinitatis vel secundum sacramentum humanae reparationis) ${ }^{33}$ an unmistakable allusion to Hugh's signature notion.

\section{The Practico-Affective Orientation of Theology and the Nature of Scripture}

It is well-known and oft-noted that the medieval Franciscans stressed the ultimately practical character and orientation of theological endeavor. This follows naturally from the foregoing. If theology is about 'God accomplishing the work of human restoration through Christ', or, as we might paraphrase, about God's activity in 'salvation history', it surprises not that theology's goal is to provide human beings with the knowledge necessary for salvation and also to facilitate their arrival thereto. In short, theology intends a saving effect on its practitioners. The Halensist refers to this last aspect as the mode of theology. How does theology bring about this goal? This leads to the last dimension of Hugonian influence on the $\mathrm{SH}$, and again it fuses a deep $\mathrm{Hu}$ gonian instinct with an Aristotelian interest in divine causality.

Chapter 4, the last in the Introductory Question on the nature of theology, asks about this modality in relation to Scripture (de modo sacrae Scripturae). Here the challenge of blending Victorine and Aristotelian is readily apparent as the Halensist asks a series of Aristotelian questions about the nature of Hugonian Scripture: In Article 1, if Scripture's mode is scientific (artificialis vel scientialis); in Article 2, what kind of certitude attends it; in the third, whether Scripture is uniformis vel multiformis, and in the fourth and last, because Scripture is indeed multiform, how is it so?

These questions all come from the new scientific way of thinking emerging in the early $13^{\text {th }}$ century, which sets the framework and the lexicon for what counts as an answer. But the answers attempt to maintain the traditional (Augustinian, monastic, Victorine) understanding of theology, now expressed in new terminology. The result is something intriguingly hybrid.

Consider Article 1: Is theology's mode scientific? Well, yes, but 'not according to the comprehension of human reason', but 'as ordered by divine wisdom for the in-

the Trinitarian mystery in the old metaphysics and the present possibility of the theological knowledge. Nevertheless, in the definition of the subject matter of theology in the Summa Halensis the salvation-historical dimension does not stand on the same level as with Hugh of St Victor, since the divina substantia as such stands now in the forefront of knowledge, while before [with Hugh] it had primarily to do with the knowledge of God's salvation-historical action toward human beings' (my translation).

33 SH I, TrInt, Q1, C2 (n. 2), Solutio, p. 5. 
struction of the soul in matters pertaining to salvation'. ${ }^{34}$ Scripture has a scientific mode (modus scientiae), but not 'according to the comprehension of truth through human reason', but 'according to the affect of piety through divine instruction'. Accordingly, Scripture uses not 'definition, analysis, and logical deduction', but rather 'precept, example, exhortation, revelation and prayer, which modes relate to the affection of piety', ${ }^{35}$ or 'lead one toward the affections of piety' ${ }^{36}$

Consider Article 2: Aristotelian science has an intellectual certainty that arises from the fact that it begins with, and proceeds from, first principles that are self-evident (per se manifestis) to the human intellect and it uses terms in their proper, nonmetaphorical, and univocal sense. In short, it has the certainty of intellectual speculation, the perspicacity of intellectual vision. What about theology? Here again, the Halensist gives no ground, but insists on a distinct sort of certitude, namely, that of the affectus not the intellectus; that coming from direct experience, not from speculation; that of taste, not of vision. ${ }^{37}$ He even refuses to give up on self-evident first

34 SH I, TrInt, Q1, C4, Ar1 (n. 4), Respondeo, p. 8: 'Dicendum quod non est modus sacrae Scripturae artis vel scientiae secundum comprehensionem rationis humanae, sed per dispositionem divinae sapientiae ad informationem animae in iis quae pertinent ad salutem. Unde Augustinus, XIV De Trinitate 2: "Non quidquid sciri ab hominibus potest in rebus humanis, ubi vanitatis vel noxiae curiositatatis est, huic scientiae tribuo, sed illud tantummodo quo fides saluberrima, quae ad veram beatitudinem ducit, gignitur, nutritur, roboratur": quae scientia est in rebus quae ad salutem pertinent.'

35 SH I, TrInt, Q1, C4, Ar1 (n. 4), Ad obiecta 2, p. 8: 'Ad secundum dicendum quod alius est modus scientiae, qui est secundum comprehensionem veritatis per humanam rationem; alius est modus scientiae secundum affectum pietatis per divinam traditionem. Primus modus definitivus debet esse, divisivus, collectivus; et talis modus debet esse in humanis scientiis, quia apprehensio veritatis secundum humanam rationem explicatur per divisiones, definitiones et ratiocinationes. Secundus modus debet esse praeceptivus, exemplificativus, exhortativus, revelativus, orativus, quia ii modi competunt affectui pietatis; et hic modus est in sacra Scriptura: unde ad Titum 1, dicitur scientia "secundum pietatem”. Praeterea, modus praeceptivus est in Lege et Evangelio, exemplificativus in historiographis, exhortativus in libris Salomonis et Epistolis, revelativus in Prophetis, orativus in Psalmis.'

36 SH I, TrInt, Q1, C4, Ar1 (n. 4), Ad obiecta 2, p. 4: 'Nota etiam quod alius modus debet esse scientiae quae habet informare affectum secundum pietatem; alius scientiae quae habet informare intellectum solum ad cognoscendam veritatem. Ille qui erit ad informationem affectus, erit per differentias quae dictae sunt, quia praecepta exempla, exhortationes, revelationes, orationes introducunt pietatis affectiones. Est autem pietas “cultus Dei”, sicut dicit Augustinus, XII De Trinitate, introducens illud Iob 28, 28, alia littera: "Ecce, pietas ipsa est sapientia”. Est autem 1 cultus Dei, "quo nunc desideramus eum videre, credimusque et speramus visuros”; desideramus caritate, credimus fide, speramus spe, secundum quas tres virtutes pietatis disciplina formatur.'

37 SH I, TrInt, Q1, C4, Ar2 (n. 5), Respondeo, p. 9: 'Est certitudo speculationis et est certitudo experientiae; praeterea, est certitudo secundum intellectum et est certitudo secundum affectum; item, est certitudo quoad animum spiritualem et est certitudo quoad animum animalem. Dico ergo quod modus theologicus est certior certitudine experientiae, certitudine quoad affectum quae est per modum gustus, in Psalmo 2 : "Quam dulcia faucibus meis eloquia tua” etc., quamvis non certior quoad speculationem intellectus, quae est per modum visus. Item, certior est homini spirituali, 
principles, arguing that theological science proceeds according to principles of truth that are perceived as self-evidently good (per se notis ut bonitatis), even as they remain not self-evidently true (occultis ut veritatis). ${ }^{38}$

But despite these attempts to go toe to toe with Aristotelian science, the Halensist now concedes:

This science is thus more of virtue/power, than of art, more wisdom than science; for it consists more in virtue and effectivity, than in contemplation and concept. I Cor. 2:4: "For our speech was not in the persuasive words of human wisdom, but in the demonstration of the spirit and of power." 39

In short, the theological science that "perfects the soul according to the affection by moving it to the good through the principles of fear and love, is properly and principally called wisdom. ${ }^{40}$

Not once in the forgoing has the Halensist mentioned Hugh or any other Victorine by name, and yet the whole ethos of this practical, affective, sapiential theology is fragrantly redolent of the Victorine's. The lexicon is high scholastic/Aristotelianscientia, principia per se nota, ut veritas, ut bonitas-but the content is basically an Augustinian sensibility flowing through the Abbey of St Victor into the $\mathrm{SH}$.

The proof of this claim comes in the last two articles of Question 4, as the focus now turns to the nature of Scripture itself and how it accomplishes this goal. Article 3 straightforwardly argues that Scripture must be manifold because the personal conditions and historical states of humans are also manifold, and thus Scripture must adapt itself to these diverse circumstances if it is to succeed: 'the teaching of Holy

quamvis incertior animali, I Cor. 2, 14: "Animalis homo non percipit ea, quae sunt spiritus Dei; spiritualis autem omnia diiudicat.",

38 SH I, TrInt, Q1, C4, Ar2 (n. 5), Ad obiecta 2, p 9: 'Dicendum quod sunt principia veritatis ut veritatis, et sunt principia veritatis ut bonitatis. Dico ergo quod aliae scientiae procedunt ex principiis veritatis ut veritatis per se notis; haec autem scientia procedit ex principiis veritatis ut bonitatis et per se notis ut bonitatis, quamvis occultis ut veritatis.' Cf., SH I, TrInt, Q1, C2 (n. 2), Ad obiecta 1-4, p. 5: 'In aliis vero scientiis, speculativis scilicet, est acceptio veri ut veri et etiam boni ut veri; in practicis autem moralibus, etsi sit acceptio veri ut boni, non tamen ut boni gratuiti sed moralis (... ).'

39 SH I, TrInt, Q1, C4, Ar2 (n. 5), Ad obiecta 2, p. 5: 'Unde haec scientia magis est virtutis quam artis et sapientia magis quam scientia; magis enim consistit in virtute et efficacia quam in contemplatione et notitia, I Cor. 2:4: "Sermo noster non in persuasibilibus humanae sapientiae verbis, sed in ostensione spiritus et virtutis.",

40 SH I, Q1, C1 (n. 1), Solutio, p. 2: 'Theologia igitur quae perficit animam secundum affectionem, movendo ad bonum per principia timoris et amoris, proprie et principaliter est sapientia.' See also SH I, Q1, C2 (n. 2), Contra f, p. 5: 'Scriptura sacra traditur secundum ordinem informationis practicae principiorum ad operationes, ut moveatur affectus secundum timorem et amorem ex fide iustitiae et misericordiae Dei' [Sacred Scripture proceeds, according to the order of instruction, from practical principles to actions, so that our affection could be moved, by fear and love, on the basis of faith in God's justice and mercy]. See Oleg Bychkov, 'The Nature of Theology in Duns Scotus and his Franciscan Predecessors,' Franciscan Studies 66 (2008): 5-62. 
Scripture, which has been ordained for human salvation, must employ a manifold modality, so that the mode matches the objective. ${ }^{, 41}$ Article 4 then asks what precisely this manifold nature of Scripture is. At first, the answer seems straightforward: the different scriptural senses, i.e. the literal, allegorical, and so forth. But the $S H$ knows of different traditions on this matter. Hugh of St Victor had proffered three: the literal-historical, the allegorical, and the tropological, while centuries earlier the Venerable Bede had included a fourth, the anagogical, along with the three that Hugh names. The $\mathrm{SH}$ strives to reconcile the two authorities and the result is telling, highlighting again the fusion of Victorine theology with newer modes of thought.

Bede's anagogical sense is added to Hugh's literal, allegorical, and tropological easily enough. The challenge is to offer a rationale for how they all fit together. The Halensist offers several options, the most interesting of which, at present, invokes the Aristotelian interest in causality, a move that is reminiscent of Part 2 above:

we say that the understanding of holy Scripture concerns either the cause or the effect. Concerning the cause, which is eternal, namely, God, there is the anagogical understanding. Concerning the effect, it can be twofold: either of things done (de facto) or of things to be done (de faciendo). If the latter, there is thus the moral or tropological understanding. If the former, [there is either the literal or the allegorical, which Hugh had defined ( ... ) ]. ${ }^{42}$

So, in a unique move in relation to medieval exegesis generally, the Halensist distinguishes Bede's anagogical sense from Hugh's other three senses, according to the distinction between uncreated cause and created effects, as he proceeds to say explicitly:

Note, therefore, that Hugh of St Victor, who said that the subject-matter of divine Scripture is the work of restoration, set down only three understandings of Scripture, which are founded on that work [of restoration], namely, the historical, the allegorical, and the tropological. But Bede, who understood the subject-matter of divine Scripture to be not only the work of restoration, but rather the [C]ause [of that work], added the anagogical sense, which understanding indeed looks to the [C]ause, just as the other three look to the effect. ${ }^{43}$

41 SH I, TrInt, Q1, C4, Ar3 (n. 6), Respondeo, p. 11: 'Relinquitur quod instructio sacrae Scripturae, quae est ordinata ad hominis salutem, debet habere modum multiformem, ut modus respondeat fini.' 42 SH I, TrInt, Q1, C4, Ar4 (p. 7), I. Respondeo, p. 12: 'Alio modo possunt accipi, ut dicamus quod intellectus sacrae Scripturae aut est de causa aut de effectu. De causa, quae aeterna est, Deus, est anagogicus intellectus. De effectu dupliciter potest esse: aut de facto aut de faciendo. Si de faciendo, sic est moralis intellectus sive tropologicus. Si de facto, hoc est dupliciter: aut enim intelligitur in prima facie litterae, hoc est per significationem verbi, et sic est litteralis sive historicus: "historia enim est rerum gestarum narratio quae in prima facie litterae continentur", sicut dicit Hugo; aut intelligitur per significationem facti, et sic est allegoricus, secundum quod dicit Hugo, quod "allegoria est cum per id quod factum dicitur, aliquod aliud factum sive in praesenti sive in futuro sive in praeterito significator.",

43 SH I, TrInt, Q1, C4, Ar4 (p. 7), Ad obiecta 1, p. 12: 'Nota ergo quod Hugo de S. Victore, qui posuit materiam divinarum Scripturarum opera restaurationis, posuit tantum tres intellectus sacrae Scripturae, qui quidem fundantur in opere, scilicet historicum, allegoricum et tropologicum. Beda vero, 
The basic distinction here is again that between God and God's works in history, especially the work of restoration. Just as the subject matter of theology is not only the works of restoration, but the very Agent of those works, so here in parallel fashion, Scripture's different senses refer not just to the divine effects in history (described by the literal, allegorical, and tropological senses), but to the divine Cause of those effects (found in the anagogical sense). Now, the interesting thing about all this is that Bede in fact said nothing about the divine Cause as the meaning of the anagogical sense. His account is innocent of any reference to causality. The Halensist is, so to speak, putting venerable Aristotelian words in the Venerable Bede's mouth, for his own purposes. In short, the Halensist has once again taken the Hugonian material and situated it within a new framework, a framework especially attentive not only to divine activity in history, but to the agential Cause of that activity.

\section{Conclusion}

As conceded above, Hugh's influence on the $S H$ is by no means limited to the 'General Introduction'. He is cited frequently throughout the first Franciscan Summa and especially dominates the discussion of the unedited Book 4, which treats the sacraments. Important as those material uses of Hugh's thought are, the operative assumption at present is that even more significant for appreciating the founding Victorine's influence on the foundational Franciscan opus are the more formal aspects. Hugh's deepest influence is architectonic: structural and organizational; and modal: providing an ethos and an orientation to the whole endeavor. In Hugh himself, the earliest Franciscans intellectuals found the model of the complete theologian, who does not separate argumentative analysis from a concern for persuasion and edification'; ${ }^{44}$ that is, one who integrates the speculative, the mystical, and the moral. Arguably, as indicated at the outset, this Hugonian influence flows through the Halensist on to Bonaventure. It seems, however, to end there. Shortly after the Seraphic Doctor, 'the Victorines went out of fashion in the elaboration of Franciscan theology', ${ }^{45}$ such that one can rightly style Bonaventure le dernier victorin. ${ }^{46}$

qui intellexit materiam divinarum Scripturarum non solum opus reparationis, immo causam, addidit anagogicum, qui quidem intellectus respicit causam, sicut alii tres effectum.'

44 Piron, 'Franciscains et victorins,' 522.

45 Piron, 'Franciscains et victorins,' 523.

46 Piron, 'Franciscains et victorins,' 522. 
